\title{
Glycated Albumin Sebagai Penanda Kontrol Glikemik Pada Penderita Diabetes Melitus Tipe 2
}

\author{
Anselmus Ake ${ }^{1}$, Made Ratna Saraswati ${ }^{1}$, I Gde Raka Widiana ${ }^{1}$
}

\footnotetext{
${ }^{1}$ Bagian/SMF IImu Penyakit Dalam Fakultas Kedokteran Universitas Udayana / Rumah Sakit Umum Pusat Sanglah, Denpasar
}

\begin{abstract}
Latar Belakang: Glycated albumin (GA) merupakan indeks kontrol glikemik yang relatif baru. GA mencerminkan status glukosa darah yang lebih pendek dibandingkan $\mathrm{HbA1C}$, yakni 2-4 minggu sebelumnya. Tujuan: untuk mengetahui apakah GA dapat digunakan sebagai penanda kontrol glikemik pada penderita DM tipe 2 (DMT2) dengan mencari sensitivitas, spesifisitas, nilai duga positif (NDP), dan nilai duga negatif (NDN) dari GA. Metode: Penelitian ini merupakan uji diagnostik, studi potong lintang, dilaksanakan di RSUP Sanglah dari Desember 2015 hingga Februari 2016 menggunakan sampel 59 pasien DMT2. Kontrol glikemik ditentukan dengan HbA1C, glukosa puasa dan glukosa 2JPP (baku emas). Hasil: Didapatkan area under ROC curve GA adalah 0,9135 (91,35\%). Didapatkan 5 cut off point GA dimana 2 cut off point menunjukkan kemampuan skrining GA yakni $\geq 18,7 \%$ dan $\geq 19 \%$, 2 cut off point menunjukkan kemampuan diagnostik GA yakni $\geq 21,4 \%$ dan 22,4\%, dan 1 cut off point optimal yakni 20,4\%. Hasil uji diagnostik dengan menggunakan tabel silang $2 \times 2$ pada masing-masing cut off point yaitu GA $\geq 18,7 \%$ sensitivitas $94,7 \%$; spesifisitas 76,2\%; NDP 87,8\%; NDN 88,9\%. GA $\geq 19 \%$ sensitivitas 89,5\%; spesifisitas 81\%; NDP 89,5\%; NDN 81\%. GA $\geq$ 20,4\% sensitivitas 81,6\%; spesifisitas 85,7\%; NDP 91,2\%; NDN 72\%. GA $\geq 21,4 \%$ sensitivitas 76,3\%; spesifisitas 90,5\%; NDP 93,5\%; NDN 67,9\%. GA $\geq 22,4 \%$ sensitivitas 63,2\%; spesifisitas 95,2\%; NDP 96\%; NDN 58,8\%. Berdasarkan uji korelasi, terdapat hubungan positif kuat antara $\mathrm{GA}$ dengan $\mathrm{HbA1C}, \mathrm{GA}$ dengan glukosa puasa dan $\mathrm{GA}$ dengan glukosa 2JPP. Kesimpulan: Pemeriksaan GA darah dapat digunakan sebagai modalitas diagnostik dalam menilai kontrol glikemik pada penderita DMT2.
\end{abstract}

Kata kunci: DMT2, HbA1C, GA, penanda kontrol glikemik

Background: Glycated albumin (GA) as a relatively new index of glycemic control. GA reflects the status of blood glucose in 2-4 weeks' duration, which is shorter than HbA1C. Objective: The purpose of this study is to determine whether GA can be used as a marker of glycemic control in patients with type 2 DM (DMT2) by determining the sensitivity, spesificity, Positive Predictive Value (PPV), and Negative Predictive Value (NPV) of GA. Methods: This study is a diagnostic, crosssectional study, conducted in Sanglah General Hospital from December 2015 to February 2016 with 59 DMT2 patients as subjects. Glycemic control was determined with $\mathrm{HbA1C}$, fasting glucose levels, and two-hour after meal glucose levels (gold standard). Results: GA 'area under the ROC curve' results are 0.9135 (91.35\%). This study found 5 GA's cut off points, two of them shown GA's ability as screening, which were $\geq 18.7 \%$ and $\geq 19.2 \%$, two cut off points reflected GA's ability as a diagnostic tool were $\geq 21.4 \%$ and $22.4 \%$, and 1 optimal cut off point that showed GA's equity, which was $20,4 \%$. Diagnostic tests using the $2 \times 2$ cross table at cut off point of $18.7 \%$, obtained a sensitivity of $94.7 \%$, a specificity of $76.2 \%$, PPV of $87.8 \%$, and a NPV of $88.9 \%$. At cut off point of $\geq 19 \%$, obtained $89.5 \%$ sensitivity, $81 \%$ specificity, PPV $89.5 \%$, and NPV $81 \%$. At cut off point of $\geq 20.4 \%$, obtained $81.6 \%$ sensitivity, $85.7 \%$ specificity, PPV $91.2 \%$, and a NPV $72 \% . \%$. At cut off point of $\geq 21.4 \%$, obtained $76.3 \%$ sensitivity, $90.5 \%$ specificity, PPV $93.5 \%$, and NPV $67.9 \%$. At cut off point of $\geq 22.4 \%$, obtained $63.2 \%$ sensitivity, $95.2 \%$ specificity, PPV $96 \%$, and a NPV 58.8\%. Spearman correlation test found a positive and strong correlation between $\mathrm{GA}$ and $\mathrm{HbA1C}$, GA and fasting glucose levels, also GA and two-hour after meal glucose levels. Conclusion: GA blood levels can be used as a diagnostic tool in assessing glycemic control in DMT2 patients.

Keywords: DMT2, HbA1C, GA, glycemic control marker
Tanggal diterima : 2 Februari 2017

Tanggal Disetujui : 15 Februari 2017

Tanggal Diterbitkan : 20 Februari 2017 penderita DM di Indonesia dari 8,4 juta pada tahun 2000 menjadi sekitar 21,3 juta pada tahun 2030. Senada dengan WHO, International Diabetes Federation (IDF) memprediksi peningkatan penderita DM dari 7,0 juta pada tahun 2009 menjadi 12,0 juta pada tahun 2030., Di Bali juga didapatkan prevalensi DM yang cukup tinggi yakni mencapai 5,9\%. ${ }^{5}$

Kontrol glikemik pada pasien diabetes melitus tipe 2 
(DMT2) secara skematik dapat digambarkan sebagai 'triad glukosa', dengan komponen Hemoglobin Adult 1C (HbA1C), kadar glukosa puasa, dan kadar glukosa 2 jam postprandial (2JPP). ${ }^{6}$

HbA1C merupakan zat yang terbentuk dari reaksi kimia antara glukosa dan hemoglobin, melalui reaksi nonenzimatik antara glukosa dengan $\mathrm{N}$-terminal valine pada rantai beta hemoglobin A. ${ }^{7}$ HbA1C mencerminkan konsentrasi glukosa darah 3 bulan sebelum pemeriksaan dan tidak dipengaruhi oleh diet sebelum pengambilan sampel darah. ${ }^{8}$

Studi yang dilakukan oleh McCance et al. tahun 1994 dalam menilai kompilkasi mikrovaskular yakni kejadian retinopati pada pasien diabetes mendapatkan cut off point optimum $\mathrm{HbA} 1 \mathrm{C}$ adalah $\geq 7 \%$ dengan nilai sensitivitas $78 \%$ dan spesifisitas $85 \%$. Cut off point glukosa puasa adalah $\geq 7,2$ $\mathrm{mmol} / \mathrm{L}(126 \mathrm{mg} / \mathrm{dL})$ dengan nilai sensitivitas $81 \%$ dan spesifisitas $80 \%$, sedangkan cut off point optimum dari glukosa 2JPP adalah $\geq 13.0 \mathrm{mmol} / \mathrm{L}(234 \mathrm{mg} / \mathrm{dL})$ dengan sensitivitas $88 \%$ dan spesifisitas $81 \%$.

Penelitian Action in Diabetes and Vascular Disease: Preterax and Diamicron Modified Release Controlled Evaluation (ADVANCE) menunjukkan sedikit keuntungan bertahap pada mikrovaskular outcome dengan $\mathrm{HbA} 1 \mathrm{C}$ mendekati normal; untuk pasien tanpa risiko hipoglikemi atau efek samping lain, kadar HbA1C yang diharapkan adalah $<7 \%$. Sebaliknya penelitian Action to Control Cardiovascular Risk in Diabetes (ACCORD) menunjukkan bahwa target HbA1C yang tidak terlampau ketat dari $<7 \%$ lebih dianjurkan pada pasien yang mendapat terapi obat hipoglikemik seperti sulfonilurea dan atau insulin yang dapat mengakibatkan hipoglikemi. ${ }^{6} \mathrm{HbA} 1 \mathrm{C}$ tidak mencerminkan perubahan glikemik dalam periode yang relatif singkat, dan akurasinya dikatakan menurun jika disertai dengan abnormalitas metabolisme hemoglobin seperti anemia dan pada pasien penyakit ginjal kronis (PGK) tahap akhir atau end stage ranal disease (ESRD). ${ }^{10,11}$

GA merupakan indeks kontrol glikemik yang tidak dipengaruhi oleh gangguan metabolisme hemoglobin. GA mencerminkan status glukosa darah yang lebih pendek dibandingkan HbA1C, yakni 2-4 minggu sebelumnya. GA tidak dipengaruhi oleh kadar protein serum, karena GA menghitung rasio antara kadar albumin glikat dengan total albumin serum. ${ }^{12}$ GA dapat lebih menangkap fluktuasi dan perubahan status glikemik lebih cepat dan nyata dibandingkan HbA1C. ${ }^{13}$

Beberapa studi pernah melaporkan nilai rujukan GA antara lain oleh Tominaga et al (1999) pada populasi orang Jepang adalah 12,3-16,9\%. Penelitian oleh Kohjuma et al (2011) mendapatkan nilai rujukan GA pada populasi Amerika adalah 11,9-15,8\%. Uji validasi oleh Ma et al (2010) pada populasi Cina didapatkan cut off point GA adalah $17,1 \%$ dengan nilai sensitivitas 76,82\% (CI: 73,64-79,79\%) dan spesifisitas 76,89\% (CI: 74,42-79,23). Oleh Roohk \& Zaidi (2008), target kendali glikemik yang diukur dengan parameter GA yang dianggap terkontrol adalah $<20 \%$, dengan nilai normalnya adalah $11-$ $16 \%$. Studi oleh $\mathrm{Pu}$ et al (2007), predective values dari GA dan HbA1C dalam menilai penyakit jantung koroner pada pasien DMT2 didapatkan area under Receiver Operating Characteristic (ROC) curve GA adalah 0,620 (62\%) lebih baik dibanding HbA1C (54,3\%) dengan cut off point $\mathrm{GA} \geq 19 \%$.

Penelitian ini bertujuan untuk mengetahui apakah GA dapat digunakan sebagai penanda kontrol glikemik penderita DMT2 dengan melakukan pemeriksaan GA dibandingkan dengan pemeriksaan $\mathrm{HbA} 1 \mathrm{C}$, glukosa puasa dan glukosa 2JPP. Hal ini dapat diketahui dengan mencari nilai sensitivitas, spesifisitas, nilai duga positif (NDP) dan nilai duga negatif (NDN) dari GA sebagai penanda kontrol glikemik pada penderita DMT2. Selain itu, pada penelitian ini akan dikaji korelasi antara GA dengan $\mathrm{HbA} 1 \mathrm{C}$, glukosa puasa dan glukosa 2JPP pada penderita DMT2.

\section{BAHAN DAN METODE}

Penelitian ini merupakan uji diagnostik dengan desain potong lintang untuk menilai kontrol glikemik pada penderita DMT2, dengan melakukan pemeriksaan GA darah dibandingkan dengan pemeriksaan $\mathrm{HbA} 1 \mathrm{C}$, glukosa puasa dan glukosa 2 JPP sebagai baku emas. Penelitian ini dilakukan di Ruang Rawat Inap dan Poliklinik Endokrin, Bagian Penyakit Dalam RSUP Sanglah-Denpasar. Penelitian dilaksanakan pada bulan Agustus 2015-Februari 2016. Uji diagnostik dilakukan untuk mendapatkan nilai sensitivitas, spesifisitas, nilai duga positif (NDP) dan nilai duga negatif (NDN) dengan menggunakan perhitungan tabel $2 \times 2 .{ }^{14}$ Analisis kurva ROC pada titik potong optimal dari uji baru GA untuk mendapatkan nilai sensitivitas dan spesifisitas yang berimbang. Uji Normalitas menggunakan uji Kolmogorovsmirnov (sampel lebih dari 50) untuk mengetahui apakah data berdistribusi normal atau tidak. Hubungan antarvariabel akan dianalisis dengan menggunakan uji korelasi dengan uji Pearson apabila data berdistribusi normal, tetapi bila data tidak berdistribusi normal, maka dilakukan uji korelasi dengan uji Spearman. Nilai p kurang dari 0,05 dianggap signifikan.

\section{HASIL DAN PEMBAHASAN}

Penelitian ini mengikutsertakan 59 subjek penelitian, yang terdiri dari 31 orang laki-laki (52,54\%) dan 28 orang perempuan $(47,46 \%)$. Sebaran data berdasarkan uji Kolmogorovsmirnov terhadap umur, HbA1C, glukosa puasa, glukosa 2JPP dan GA pada 59 subjek penelitian, didapatkan distribusi yang tidak normal. Subjek penelitian mempunyai rentang umur 37- 
77 tahun dengan median umur adalah 52 tahun. Median kadar HbA1C pada penelitian ini adalah 8,4\% dengan rentang nilai 5,6-16,3\%. Median kadar glukosa puasa sebesar $161 \mathrm{mg} / \mathrm{dL}$ dengan rentang nilai 77-399 mg/dL.

Tabel 1 Gambaran karakteristik subyek penelitian $(\mathrm{n}=59)$

\begin{tabular}{lllll}
\hline & \multicolumn{2}{c}{ Nilai } & & \\
\cline { 2 - 5 } & Jumlah & \% & Median & Range \\
\hline Jenis Kelamin & & & & \\
Laki-laki & 31 & 52,54 & & \\
Perempuan & 28 & 47,46 & & \\
Umur (tahun) & & & 52 & $33-77$ \\
HbA1C (\%) & & & 8,4 & $5,6-16,3$ \\
Glukosa puasa (mg/dL) & & & 161 & $77-399$ \\
Glukosa 2JPP (mg/dL) & & & 220 & $97-525$ \\
GA (\%) & & & 21,5 & $13,5-64,2$ \\
\hline
\end{tabular}

Pemeriksaan kadar GA darah dilakukan bersamaan dengan pemeriksaan kadar HbA1C, kadar glukosa puasa dan kadar glukosa 2JPP. Hasil pemeriksaan kadar GA pada penelitian ini berada pada kisaran 13,5-64,2\%, dengan median $21,5 \%$. Penilaian kontrol glikemik dengan menggunakan GA sebagai uji baru pada penelitian ini dikategorikan tidak terkontrol menggunakan nilai batas yang ditentukan dengan kurva ROC. Pada penelitian ini didapatkan hasil area under ROC curve GA adalah 0,9135 (91,35\%) yang artinya kemampuan nilai diagnostik dari GA sebagai penanda kontrol glikemik pada penderita DMT2 adalah sangat baik. Dalam penelitian ini, peneliti mendapatkan 5 cut off point GA dimana 2 cut off point digunakan sebagai batas yang menunjukkan kemampuan GA dalam hal skrining kontrol glikemik buruk dengan lebih menonjolkan nilai sensitivitas tanpa mengorbankan nilai spesifisitas yakni $\geq 18,7 \%$ dan $\geq 19 \%$, 2 cut off point digunakan sebagai batas yang menunjukkan kemampuan GA dalam hal diagnostik kontrol glikemik buruk dengan lebih menonjolkan nilai spesifisitas tanpa mengorbankan nilai sensitivitas yakni $\geq 21,4 \%$ dan $22,4 \%$, dan 1 cut off point digunakan sebagai batas optimal yang menunjukkan kemampuan GA yang berimbang

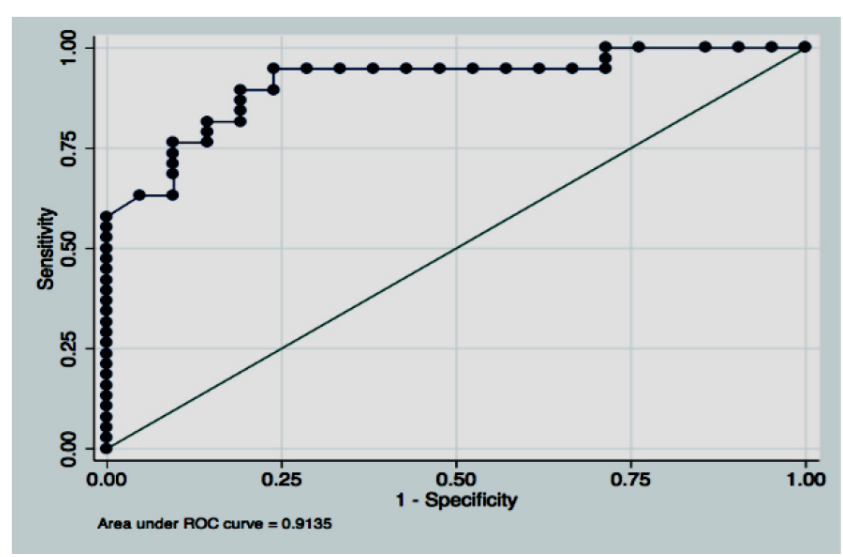

Gambar 1. Kurva ROC kemampuan GA sebagai penanda kontrol glikemik

baik dalam hal skrining maupun dalam hal diagnostik yakni $20,4 \%$

Beberapa studi pernah melaporkan nilai rujukan GA antara lain oleh Tominaga et al (1999) pada populasi orang Jepang adalah 12,3-16,9\%. Penelitian oleh Kohjuma et al (2011) mendapatkan nilai rujukan GA pada populasi Amerika adalah 11,9-15,8\%. Oleh Roohk \& Zaidi (2008), target kendali glikemik yang diukur dengan parameter GA yang dianggap terkontrol adalah $<20 \%$, dengan nilai normalnya adalah 11 $16 \%$. Studi oleh Pu et al (2007), predective values dari GA dan HbA1C dalam menilai penyakit jantung koroner pada pasien DMT2 didapatkan area under ROC curve GA adalah 0,620 (62\%) lebih baik dibanding HbA1C (54,3\%) dengan cut off point $\mathrm{GA} \geq 19 \%$. Cut off point GA dalam menentukan target kontrol glikemik yang didapatkan pada penelitian ini berada dalam rentang nilai dari penelitian tersebut di atas.

Untuk menilai sensitivitas, spesifisitas, NDP, NDN dari GA sebagai penanda kontrol glikemik dipakai uji diagnostik menggunakan tabel silang $2 \times 2$. Hasil analisis dengan menggunakan cut off point yang menunjukkan kemampuan GA dalam hal skrining kontrol glikemik buruk disajikan pada Tabel 2 dan Tabel 3.

Tabel 2. Uji diagnostik antara HbA1C, glukosa puasa, glukosa 2JPP dan GA (cut off point $\mathrm{GA} \geq 18,7$ )

\begin{tabular}{|c|c|c|c|c|}
\hline & & $\begin{array}{l}\text { HbA1C(\%), GDP } \\
\text { dan glukosa } 2 \text { JPP (mg/ }\end{array}$ & & \\
\hline & Kelompok & Tidak Terkontrol & Terkontrol & Jumlah \\
\hline & & $\begin{array}{l}\text { HbA1C } \geq 7, \text { GDP }>100, \\
\text { Glukosa } 2 \text { JPP }>140\end{array}$ & $\begin{array}{l}\text { HbA1C }<7, \text { GDP }<100, \\
\text { Glukosa } 2 \text { JPP }<140\end{array}$ & \\
\hline GA & Tidak terkontrol $(\geq 18,7)$ & 36 & 5 & 41 \\
\hline (\%) & Terkontrol $(<18,7)$ & 2 & 16 & 18 \\
\hline Jum & & 38 & 21 & 59 \\
\hline
\end{tabular}


Berdasarkan hasil analisis dengan menggunakan tabel silang $2 \times 2$ dengan cut off point GA sebagai batas yang menunjukkan kemampuan GA dalam hal skrining kontrol glikemik buruk yakni $\geq 18,7 \%$ didapatkan sensitivitas $94,7 \%$ (CI 82,3-99,4), spesifisitas 76,2\% (CI 52,8-91,8), NDP 87,8\% (CI 73,8-95,9), dan NDN 88,9\% (CI 65,3-98,6). Cut off point $\geq 19 \%$ didapatkan sensitivitas $89,5 \%$ (CI 75,2-97,1), spesifisitas
81\% (CI 58,1-94,6), NDP 89,5\% (CI 75,2-97,1), dan NDN 81\% (CI 58,1-94,6).

Berdasarkan hasil analisis dengan menggunakan tabel silang $2 \times 2$ dengan cut off point optimal yakni $\geq 20,4 \%$ didapatkan sensitivitas $81,6 \%$ (CI 65,7-92,3\%), spesifisitas 85,7\% (CI 63,797\%), NDP 91,2\% (CI 76,3-98,1\%), dan NDN 72\% (CI 50,6$87,9 \%)$.

Tabel 3. Uji diagnostik antara HbA1C, glukosa puasa, glukosa 2JPP dan GA (cut off point $\mathrm{GA} \geq 19 \%$ )

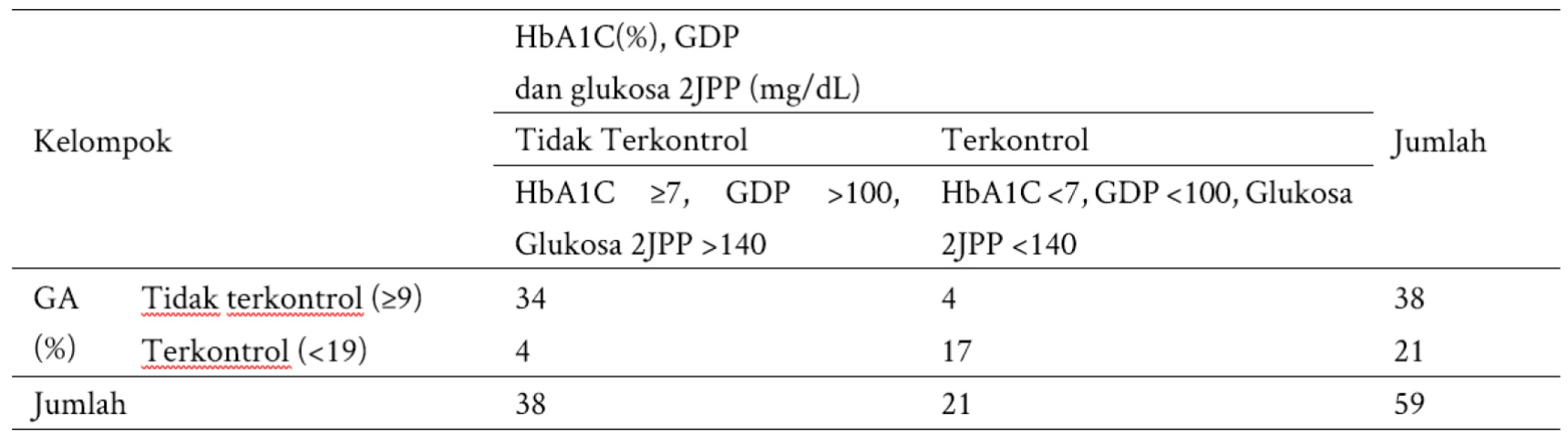

Tabel 4. Uji diagnostik antara HbA1C, glukosa puasa, glukosa 2JPP dan GA (cut off point $\mathrm{GA} \geq 20,4 \%$ )

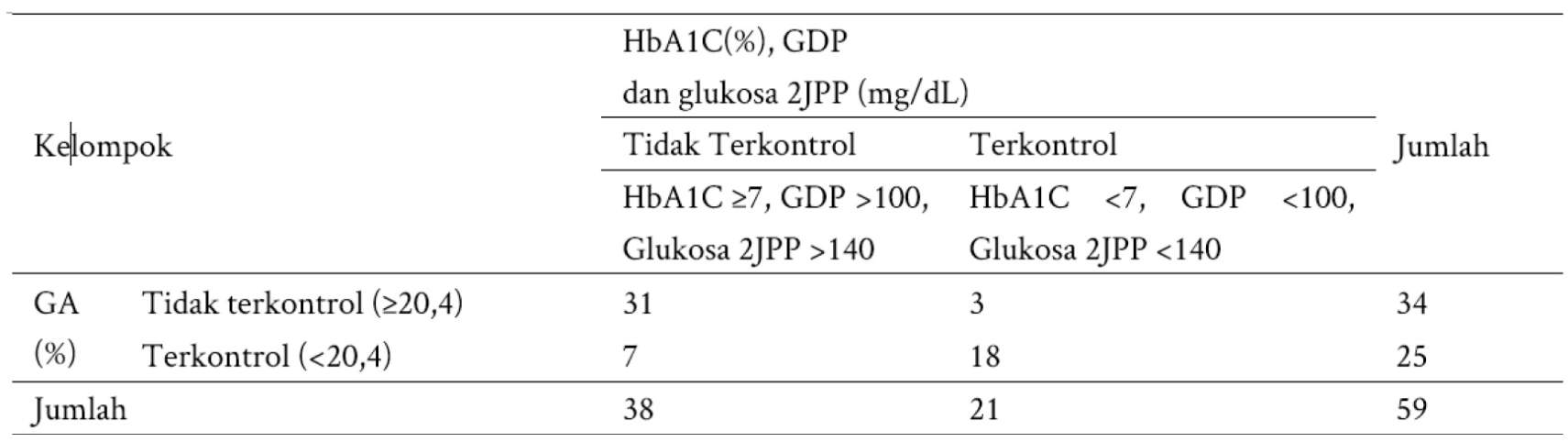

Tabel 5. Uji diagnostik antara HbA1C, glukosa puasa, glukosa 2JPP dan GA (cut off point $\mathrm{GA} \geq 21,4 \%$ )

\begin{tabular}{|c|c|c|c|c|}
\hline \multirow{3}{*}{\multicolumn{2}{|c|}{ Kelompok }} & \multicolumn{2}{|c|}{$\begin{array}{l}\text { HbA1C(\%), GDP } \\
\text { dan glukosa 2JPP (mg/dL) }\end{array}$} & \multirow{3}{*}{ Jumlah } \\
\hline & & \multirow{2}{*}{$\begin{array}{l}\text { Tidak Terkontrol } \\
\text { HbA1C } \geq 7, \text { GDP }>100, \\
\text { Glukosa } 2 J P P>140\end{array}$} & \multirow{2}{*}{$\begin{array}{l}\text { Terkontrol } \\
\text { HbA1C }<7, \text { GDP }<100, \\
\text { Glukosa 2JPP }<140\end{array}$} & \\
\hline & & & & \\
\hline \multirow{2}{*}{$\begin{array}{l}\text { GA } \\
(\%)\end{array}$} & Tidak terkontrol $(\geq 21,4)$ & 29 & 2 & 31 \\
\hline & Terkontrol $(<21,4)$ & 9 & 19 & 28 \\
\hline \multicolumn{2}{|c|}{ Jumlah } & 38 & 21 & 59 \\
\hline
\end{tabular}


Tabel 6. Uji diagnostik antara HbA1C, glukosa puasa, glukosa 2JPP dan GA (cut off point $\mathrm{GA} \geq 22,4 \%$ )

\begin{tabular}{|c|c|c|c|c|}
\hline \multirow{3}{*}{\multicolumn{2}{|c|}{ Kelompok }} & \multicolumn{2}{|c|}{$\begin{array}{l}\text { HbA1C(\%), GDP } \\
\text { dan glukosa 2JPP (mg/dL) }\end{array}$} & \multirow{3}{*}{ Jumlah } \\
\hline & & \multirow{2}{*}{$\begin{array}{l}\text { Tidak Terkontrol } \\
\text { HbA1C } \geq 7, \text { GDP }>100, \\
\text { Glukosa } 2 J P P>140\end{array}$} & \multirow{2}{*}{$\begin{array}{l}\text { Terkontrol } \\
\text { HbA1C }<7, \text { GDP }<100, \\
\text { Glukosa } 2 J P P<140\end{array}$} & \\
\hline & & & & \\
\hline \multirow{2}{*}{$\begin{array}{l}\text { GA } \\
(\%)\end{array}$} & Tidak terkontrol $(\geq 22,4)$ & 24 & 1 & 25 \\
\hline & Terkontrol $(<22,4)$ & 14 & 20 & 34 \\
\hline \multicolumn{2}{|c|}{ Jumlah } & 38 & 21 & 59 \\
\hline
\end{tabular}

Tabel 7. Hasil analisis pada masing-masing cut off point GA GA, Glycated albumin; NDP, Nilai duga positif; NDN, Nilai duga negatif *)Nilai yang diikuti oleh superskrip pada kolom yang sama menunjukkan kemampuan GA yang berimbang sebagai penanda kontrol glikemik pada cut off point optimal

\begin{tabular}{|c|c|c|c|c|c|}
\hline & \multicolumn{5}{|c|}{ Cut off point GA (\%) } \\
\hline & $\geq 18,7$ & $\geq 19$ & $\left.\geq 20,4^{*}\right)$ & $\geq 21,4$ & $\geq 22,4$ \\
\hline Sensitivitas & 94,7 & 89,5 & 81,6 & 76,3 & 63,2 \\
\hline (95\% CI) & $(82,3-99,4)$ & $(75,2-97,1)$ & $(65,7-92,3)$ & $(59,8-88,6)$ & $(46-78,2)$ \\
\hline Spesifisitas & 76,2 & 81 & 85,7 & 90,5 & 95,2 \\
\hline (95\% CI) & $(52,8-91,8)$ & $(58,1-94,6)$ & $(63,7-97)$ & $(69,6-98,8)$ & $(76,2-99,9)$ \\
\hline NDP & 87,8 & 89,5 & 91,2 & 93,5 & 96 \\
\hline$(95 \% \mathrm{CI})$ & $(73,8-95,9)$ & $(75,2-97,1)$ & $(76,3-98,1)$ & $(78,6-99,2)$ & $(79,6-99,9)$ \\
\hline NDN & 88,9 & 81 & 72 & 67,9 & 58,8 \\
\hline$(95 \% \mathrm{CI})$ & $(65,3-98,6)$ & $(58,1-94,6)$ & $(50,6-87,9)$ & $(47,6-84,1)$ & $(40,7-75,4)$ \\
\hline
\end{tabular}

Berdasarkan hasil analisis dengan menggunakan tabel silang $2 \times 2$ dengan cut off point GA sebagai batas yang menunjukkan kemampuan GA dalam hal diagnostik kontrol glikemik buruk yakni $\geq 21,4 \%$ didapatkan sensitivitas 76,3\% (CI 59,8-88,6\%), spesifisitas 90,5\% (CI 69,6-98,8\%), NDP 93,5\% (CI 78,6-99,2\%), dan NDN 67,9\% (CI 47,6-84,1\%). Cut off point $\geq 22,4 \%$ didapatkan sensitivitas $63,2 \%$ (CI 46-78,2\%), spesifisitas 95,2\% (CI 76,2-99,9\%), NDP 96\% (CI 79,6-99,9\%), dan NDN 58,8\% (CI 40,7-75,4\%).

Kontrol glikemik pada pasien DMT2 secara skematik dapat digambarkan sebagai 'triad glukosa', dengan komponen HbA1C, kadar glukosa puasa, dan kadar glukosa postprandial. Saat ini ada dua nilai $\mathrm{HbA} 1 \mathrm{C}$ yang digunakan untuk menilai diabetes yang terkontrol yaitu: 7\% oleh ADA dan 6,5\% oleh AACE dan IDF. ${ }^{6}$ Kadar glukosa puasa dikategorikan terkontrol bila $<100 \mathrm{mg} / \mathrm{dL}$ dan kadar glukosa 2JPP dikategorikan terkontrol bila $<140 \mathrm{mg} / \mathrm{dL}^{3}$ Pada penelitian ini nilai HbA1C yang digunakan untuk menilai diabetes yang terkontrol yaitu 7\%, kadar glukosa puasa dikategorikan terkontrol bila $<100 \mathrm{mg} / \mathrm{dL}$ dan kadar glukosa 2JPP dikategorikan terkontrol bila $<140 \mathrm{mg} / \mathrm{dL}$.

Pada beberapa keadaan, HbA1C tidak dapat mencerminkan kontrol glukosa darah. Hal ini penting diketahui karena dapat menyebabkan under atau overtreatment. HbA1C tidak mencerminkan perubahan glikemik dalam periode yang relatif singkat, dan akurasinya dikatakan menurun jika disertai dengan abnormalitas metabolisme hemoglobin seperti anemia dan pada pasien PGK tahap akhir atau ESRD. Pemeriksaan kadar glukosa sangat berfluktuasi dan hasilnya dapat dipengaruhi oleh stres, penundaan pemeriksaan serum, merokok serta aktivitas sebelum uji laboratorium dilakukan.,11,15,16 Untuk itu, diperlukan sebuah penanda baru seperti GA sebagai alternatif pemeriksaan dalam menilai kontrol glikemik..$^{12,17}$ 


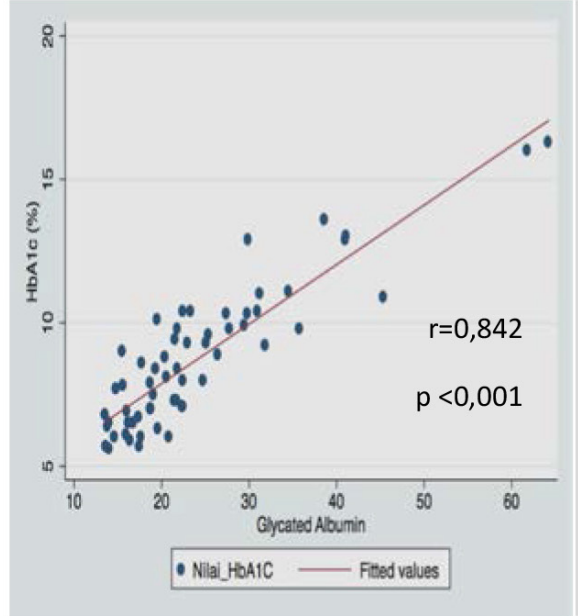

(a). Hubungan GA dengan $\mathrm{HbAlC}$

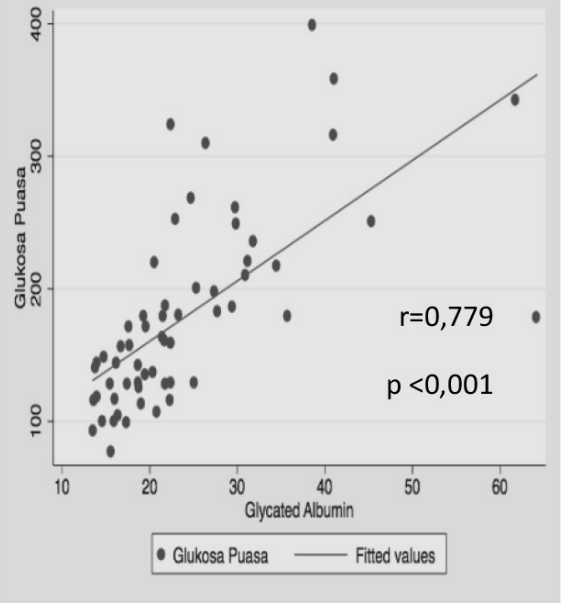

(b). Hubungan GA dengan glukosa puasa

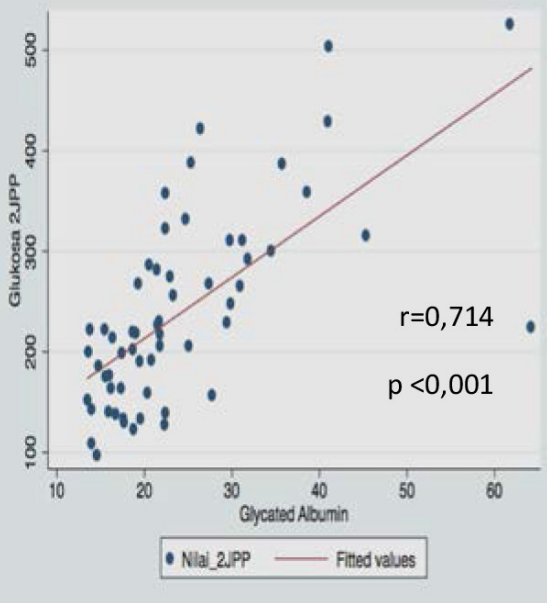

(c). Hubungan GA dengan glukosa 2JPP

Gambar 2. Hubungan antara GA dengan HbA1C, glukosa puasa dan glukosa 2JPP

Menurut Roohk \& Zaidi (2008), target kendali glikemik yang diukur dengan parameter GA yang dianggap terkontrol adalah $<20 \%$, dengan nilai normalnya adalah $11-16 \%$.

Uji validasi oleh Ma et al (2010) pada populasi Cina didapatkan cut off GA adalah 17,1\% dengan nilai sensitivitas 76,82\% (CI: 73,64-79,79\%) dan spesifisitas 76,89\% (CI: 74,4279,23). Penelitian lain oleh Yang et al (2012) didapatkan cut off dari GA 15,7\% dengan nilai sensitivitas 73,3\% (CI: 73,6479,79\%) dan spesifisitas 80,1\% (CI: 74,42-79,23).

Dua cut off point GA yakni $\geq 18,7 \%$ dan $\geq 19 \%$ pada penelitian ini mendapatkan nilai sensitivitas yang lebih menonjol tanpa mengorbankan nilai spesifisitas, hal ini menjelaskan bahwa GA cukup baik digunakan sebagai skrining kontrol glikemik buruk pada penderita DMT2. Cut off point GA $\geq 21,4 \%$ dan $\geq 22,4 \%$ dengan nilai spesifisitas yang lebih menonjol tanpa mengorbankan nilai sensitivitas menjelaskan bahwa GA cukup baik digunakan untuk diagnostik kontrol glikemik buruk pada penderita DMT2. Cut off point $\geq 20,4 \%$ dianggap sebagai cut off point GA yang optimal dengan nilai sensitivitas dan spesifisitas yang cukup berimbang.

Berdasarkan uji Kolmogorov-smirnov terhadap GA dengan HbA1C, glukosa puasa dan glukosa 2JPP pada 59 subjek penelitian, didapatkan distribusi yang tidak normal sehingga dipakai uji korelasi Spearman. Pada penelitian ini didapatkan hubungan positif kuat antara GA dengan HbA1C ( $r=0,842$ dengan nilai $p<0,001$ ), GA dengan glukosa puasa ( $\mathrm{r}=0,779$ dengan nilai $\mathrm{p}<0,001)$ dan GA dengan glukosa 2JPP $(\mathrm{r}=0,714$ dengan nilai $\mathrm{p}<0,001)$. Hasil uji korelasi tersebut dapat dilihat pada gambar 2 .

Temuan hubungan positif kuat pada penelitian ini sesuai dengan temuan pada penelitian sebelumnya yang dilakukan oleh Ma et al (2010) yang menunjukkan hubungan yang kuat antara GA dengan $\mathrm{HbA1C}(\mathrm{r}=0,699, \mathrm{p}<0,001)$, GA dengan glukosa puasa $(r=0,640, p<0,001)$ dan GA dengan glukosa 2JPP $(\mathrm{r}=0,661, \mathrm{p}<0,001)$. Penelitian lain oleh $\mathrm{Pu}$ et al (2007) juga menunjukkan hubungan yang kuat antara GA dengan $\mathrm{HbA1c}(\mathrm{r}=0,795, \mathrm{p}<0,001)$. Hasil yang sama juga didapatkan oleh Yang et al (2012) di mana terdapat hubungan yang kuat antara GA dengan $\mathrm{HbA1C}(\mathrm{r}=0,8976$, $\mathrm{p}<0001)$, GA dengan glukosa puasa $(\mathrm{r}=0,8097, \mathrm{p}<0001)$ dan GA dengan glukosa 2JPP $(r=0,6545, p<0,0001)$. Dalam penelitian ini, hubungan positif kuat yang paling baik adalah hubungan antara GA dengan HbA1C dengan nilai $r=0,842$. Hal ini menunjukkan bahwa GA lebih berkorelasi baik dengan HbA1C jika dibandingkan dengan glukosa puasa dan glukosa 2JPP yang artinya GA lebih mencerminkan kontrol glikemik jangka panjang dalam penatalaksanaan DM.

\section{KESIMPULAN}

Temuan hubungan positif kuat dalam penelitian ini menunjukkan bahwa pemeriksaan GA dapat digunakan sebagai pemeriksaan tambahan dalam mendeteksi pasien diabetes maupun sebagai penanda kontrol glikemik pada pasien diabetes.

\section{DAFTAR PUSTAKA}

1. American Diabetes Association. 2010. Position statement: standards of medical care in diabetes 2010. Diab Care; 33(Suppl.1)

2. International Diabetes Federation. 2012. IDF diabetes atlas 2012 updated (poster format). $5^{\text {th }}$ edition. Brussels: International Diabetes Federation. p. 1-2 


\section{ARTIKEL ASLI}

Jurnal Penyakit Dalam Udayana

Udayana Journal of Internal Medicine

Volume 1, No 1: 2017

3. Perkumpulan Endokrinologi Indonesia. 2011. Konsensus pengelolaan dan pencegahan diabetes melitus tipe 2 di indonesia. Jakarta: PB. PERKENI. p. 1-62

4. International Diabetes Federation. 2005. IDF guidelines task force. global guideline for type 2 diabetes. Brussels: International Diabetes Federation. p. 1-82

5. Suastika, Ketut. 2008. Kumpulan naskah ilmiah (obesitas, sindroma metabolik, diabetes, dislipidemia dan penyakit tiroid).Denpasar: Udayana University Press. p.220-225

6. Monnier, L \& Colette, C. 2009. Target for glycemic control. Diabetes Care; 32 (Suppl. 2): 199-204

7. Mahajan, R.D., Mishra, B. 2011. Using glycated hemoglobin hba1c for diagnosis of diabetes mellitus: an indian perspective. Int J Biol Med Res; 2(2): 508-512

8. Schneider, H., Shaw, J., Zimmet, P. 2003. Guidelines for the detection of diabetes mellitus: diagnostic criteria and rationale for screening. Clin Biochem Rev; 24: 77-80

9. World Health Organization. 2011. Use of glycated haemoglobin (hba1c) in the diagnosis of diabetes mellitus. Abbreviated Report of a WHO Consultation; 1-25

10. American Diabetes Association. 2012. Position statement: standards of medical care in diabetes 2012. Diab Care; 35(Suppl.1)

11. Peacock, T.P., Shihabi, Z.K., Bleyer, A.J., Dolbare, E.L., Byers, J.R., Knovich, M.A., et al. 2008. Comparison of glycated albumin and hemoglobin A1c levels in diabetic subjects on hemodialysis. Kidney International; 73: 10621068
12. Koga, M. \& Kasayama, M. 2010. Clinical impact of glycated albumin as another glycemic control marker. Endocrine Journal; 57(9): 751-762

13. Yoshiuchi, K., Matsuhisa, M., Katakami, M., Nakatani, Y., Sakamoto, K., Matsuoka, T., et al. 2008. Glycated albumin is a better indicator for glucose excursion than glycated hemoglobin in type 1 and type 2 diabetes. Endocrine Journal; 55 (3): 503-507

14. Sastroasmoro, S. 2010. Dasar-dasar Metodelogi Penelitian Klinis. Jakarta: CV Sagung Seto. p. 321

15. Nitin, S. 2010. HbA1c and factors other than diabetes mellitus affecting it. Singapore Med J; 51(8): 616-622

16. Son, J.I., Rhee1, S.Y., Woo1, J.T., Hwang, J.K., Chin, S.O., Chon, S., et al. 2013. Hemoglobin a1c may be an inadequate diagnostic tool for diabetes mellitus in anemic subjects. Diabetes Metab J; 37: 343-348

17. Arasteh, A., Farahi, S., Rezaei, M.H., Movahedi, A.A.M., 2014. Glycated albumin: an overview of the in vitro models of an in vivo potential disease marker. Journal of Diabetes \& Metabolic Disorders; 13: 49

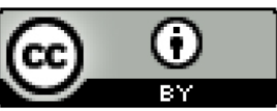

This work is licensed under a Creative Commons Attribution 4.0 International License. 